\title{
Advances in Public Transport Platform for the Development of Sustainability Cities
}

\author{
Juan M. Corchado ${ }^{1}$, Josep L. Larriba-Pey ${ }^{2}$, Pablo Chamoso-Santos ${ }^{1}\left(\mathbb{D}\right.$ and Fernando De la Prieta Pintado ${ }^{1, *}$ (I) \\ 1 BISITE Research Group, University of Salamanca, Edificio Multiusos I + D + I, 37007 Salamanca, Spain; \\ corchado@usal.es (J.M.C.); chamoso@usal.es (P.C.-S.) \\ 2 Data Management Group, Polytechnic University of Catalonia, 08034 Barcelona, Spain; larri@ac.upc.edu \\ * Correspondence: fer@usal.es; Tel.: +34-677-522-678
}

\section{check for}

updates

Citation: Corchado, J.M.;

Larriba-Pey, J.L.; Chamoso-Santos, P.; De la Prieta Pintado, F. Advances in Public Transport Platform for the Development of Sustainability Cities. Electronics 2021, 10, 2771. https:// doi.org/10.3390/electronics10222771

Received: 4 November 2021

Accepted: 11 November 2021

Published: 12 November 2021

Publisher's Note: MDPI stays neutral with regard to jurisdictional claims in published maps and institutional affiliations.

Copyright: (C) 2021 by the authors Licensee MDPI, Basel, Switzerland. This article is an open access article distributed under the terms and conditions of the Creative Commons Attribution (CC BY) license (https:// creativecommons.org/licenses/by/ $4.0 /)$.

\section{Introduction}

There is high and varied mobility in modern societies which requires a complex transport system that adapts to social needs and guarantees the movement of people and goods in an economically efficient and safe way. All this designed from the new perspective of environmental wellness and of the sustainability paradigm. From this viewpoint, an efficient and flexible transport system that provides intelligent and sustainable mobility patterns is essential to our economy and quality of life. The current transport system poses growing and significant challenges for the environment, human health, and sustainability. Existent mobility schemes focus excessively on the use of private vehicles which have conditioned the lifestyle of citizens in cities, as well as urban and territorial sustainability.

Transport is an important element of the sustainable development framework due to the growing environmental strain, the associated social and economic effects, and its interconnection with other sectors. The continuous growth that this sector has experienced over the last few years and its foreseeable future growth, even considering the change of trend caused by the current situation of generalized crisis, make the challenge of sustainable transport a strategic priority at local, national, European, and global levels.

\section{The Present Issue}

This special issue consists of sixteen papers covering important topics in the field of public transportation under the framework of smart cities.

The research community is now turning its attention to different areas such as optimization and prediction [1-5]. As evidenced in references [2,3,5], which have analyzed travel time data to evaluate the performance of a public transport system. Others have focused on the demand for different modes of transportation and interaction among them, including a proposal for minimizing the passengers' waiting times and maximizing the vehicles' occupancy ratios. The use of unmanned aerial vehicles for emergency situations is extensively described in [1] for search and rescue operations, surveillance, disaster monitoring, response to terrorist attacks. Finally, ref. [4] studied the influence of the economy on transportation systems.

Recommender Systems are also commonly used within the framework of transportation for sustainable cities. Hence, references [6,7] focused on offering improved usability and services based on multi-modal door-to-door passenger experiences to increase engagement. Other examples can be found in reference [8], where recommendation systems are designed to improve the passengers' experience and the drivers' profit. Finally, other approaches focused on educating the general public about this topic [9].

Other topics included in this special issue are energy consumption forecasting in sustainable cities [10] as well as the analysis of energy trading and the development of a trust model [11]. Security is also an important issue within public transpormation, in reference [12] the secure management of railway transportation systems has been analyzed. 
Finally, analytical models using Machine Learning and Deep Learning have been explored as part of this special issue $[13,14]$. Also, two case studies, carried out in the city of Barcelona, Spain [15] and Taipei, Taiwan [15], have been described.

\section{Conclusions}

This special issue has paid attention to all the research approaches that focus on the relationship between the evolution of transportation and the new perspective of achieving environmental wellness and efficiency, which has become one of the cornerstones of sustainability. It revolves around producing, consuming, and transporting people and goods better, while using up fewer resources and having lower environmental impact.

Author Contributions: J.M.C., J.L.L.-P., P.C.-S. and F.D.1.P.P. worked together in the whole editorial process of the special issue, "Advances in Public Transport Platform for the Development of Sustainability Cities", published by journal Electronics. F.D.l.P.P. drafted this editorial summary. J.M.C., J.L.L.-P. and P.C.-S. reviewed, edited, and finalized the manuscript. All authors have read and agreed to the published version of the manuscript.

Funding: This research was funded by "Ministerio de Ciencia, Innovación y Universidades. Proyectos I + D + i «RETOS INVESTIGACIÓN» del Programa Estatal de I+D+i orientada a los retos de la sociedad", grant number RTI2018-095390-B-C32. This research was also funded by the Shift2Rail Joint Undertaking under the Europeans Union's Horizon 2020 Research and Innovation Programme, grant number 777640 .

Acknowledgments: First of all, we would like to thank all researchers who submitted articles to this special issue for their excellent contributions. We are also grateful to all the reviewers who helped in the evaluation of the manuscripts and made very valuable suggestions to improve the quality of the contributions. We would like to acknowledge the editorial board of Electronics, who invited us to guest edit this special issue. We are also grateful to the Electronics Editorial Office staff who worked thoroughly to maintain the rigorous peer-review schedule and timely publication.

Conflicts of Interest: The authors declare no conflict of interest.

\section{References}

1. Saha, S.; Vasegaard, A.E.; Nielsen, I.; Hapka, A.; Budzisz, H. UAVs Path Planning under a Bi-Objective Optimization Framework for Smart Cities. Electronics 2021, 10, 1193. [CrossRef]

2. Hartmann Tolić, I.; Nyarko, E.K.; Ceder, A. Optimization of Public Transport Services to Minimize Passengers' Waiting Times and Maximize Vehicles' Occupancy Ratios. Electronics 2020, 9, 360. [CrossRef]

3. Martin, L.; Wittmann, M.; Li, X. The Influence of Public Transport Delays on Mobility on Demand Services. Electronics 2021, 10, 379. [CrossRef]

4. Sousa, R.; Lima, T.; Abelha, A.; Machado, J. Hierarchical Temporal Memory Theory Approach to Stock Market Time Series Forecasting. Electronics 2021, 10, 1630. [CrossRef]

5. Yuan, Y.; Shao, C.; Cao, Z.; He, Z.; Zhu, C.; Wang, Y.; Jang, V. Bus Dynamic Travel Time Prediction: Using a Deep Feature Extraction Framework Based on RNN and DNN. Electronics 2020, 9, 1876. [CrossRef]

6. García-Retuerta, D.; Rivas, A.; Guisado-Gámez, J.; Antoniou, E.; Chamoso, P. Reputation System for Increased Engagement in Public Transport Oriented-Applications. Electronics 2021, 10, 1070. [CrossRef]

7. Rivas, A.; González-Briones, A.; Cea-Morán, J.J.; Prat-Pérez, A.; Corchado, J.M. My-Trac: System for Recommendation of Points of Interest on the Basis of Twitter Profiles. Electronics 2021, 10, 1263. [CrossRef]

8. Wan, X.; Ghazzai, H.; Massoud, Y. A Generic Data-Driven Recommendation System for Large-Scale Regular and Ride-Hailing Taxi Services. Electronics 2020, 9, 648. [CrossRef]

9. Jordán, J.; Valero, S.; Turró, C.; Botti, V. Using a Hybrid Recommending System for Learning Videos in Flipped Classrooms and MOOCs. Electronics 2021, 10, 1226. [CrossRef]

10. Oliveira, P.; Fernandes, B.; Analide, C.; Novais, P. Forecasting Energy Consumption of Wastewater Treatment Plants with a Transfer Learning Approach for Sustainable Cities. Electronics 2021, 10, 1149. [CrossRef]

11. Andrade, R.; Wannous, S.; Pinto, T.; Praça, I. Extending a Trust model for Energy Trading with Cyber-Attack Detection. Electronics 2021, 10, 1975. [CrossRef]

12. Hatzivasilis, G.; Fysarakis, K.; Ioannidis, S.; Hatzakis, I.; Vardakis, G.; Papadakis, N.; Spanoudakis, G. SPD-Safe: Secure Administration of Railway Intelligent Transportation Systems. Electronics 2021, 10, 92. [CrossRef]

13. Taboada, G.L.; Han, L. Exploratory Data Analysis and Data Envelopment Analysis of Urban Rail Transit. Electronics 2020, 9 , 1270. [CrossRef] 
14. Hernández-Nieves, E.; Parra-Domínguez, J.; Chamoso, P.; Rodríguez-González, S.; Corchado, J.M. A Data Mining and Analysis Platform for Investment Recommendations. Electronics 2021, 10, 859. [CrossRef]

15. Mariñas-Collado, I.; Frutos Bernal, E.; Santos Martin, M.T.; Martín del Rey, A.; Casado Vara, R.; Gil-González, A.B. A Mathematical Study of Barcelona Metro Network. Electronics 2021, 10, 557. [CrossRef] 